\begin{tabular}{c} 
Volume and Issues Obtainable at Center for Sustainability Research and Consultancy \\
Sustainable Business and Society in Emerging Economies \\
ISSN: 2708-2504 ISSN (E) 2708-2172 \\
Volume 1: No. 2, December2019 \\
ᄃSRᄃ \\
Journal homepage: www.publishing.globalcsrc.org/sbsee \\
\hline
\end{tabular}

\title{
E-Money Challenge in Disruption Era: Uncovering the Dilemma Issues from Consumers' Perspective
}

\author{
${ }^{1}$ Cut Irna Setiawati, ${ }^{2}$ Nurul Falah
}

${ }^{1}$ Lecturer, Department of Business Administration, Telkom University, irnacut@telkomuniversity.ac.id

${ }^{2}$ Student, Department of Business Administration, Telkom University, nurulfalahh@gmail.com

\begin{tabular}{l} 
ARTICLE DETAILS \\
\hline History \\
Revised format: November 2019 \\
Available Online: December 2019
\end{tabular}

Keywords

E-Money, Determinant

Factors, Payment, Factoring

Analysis

\section{JEL Classification:}

P24, E49,

\section{ABSTRACT}

The purpose of this paper is to determine factors that drive e-money provider system named Link Aja (produced by Telkomsel, a telecommunication company in Indonesia) users to become less active in using Link Aja, especially users located in Bandung, by remembering some potential commerce and trading conducted in the city that have great potential benefits if all transaction are supported by e-money Link Aja. This study uses quantitative methods with descriptive and exploration research types. The technique of collecting data has spread the questionnaire to users in Bandung who have an account but less active in using Link Aja. Factoring Analysis as statistical tools were used to analyze the data and test the hypotheses. There are six factors which determine the decreasing of Link Aja users activity in transaction, consist of (1) Security and limited discount, (2) Explicit fees, (3) Machine and update system unpredictable, (4) Networks, (5) Confuse term and condition, and (6) Disadvantage of time and popularity. This research presents update factors in terms of activity in using e-money from the opposite perspective (less active side), in completing factors of e-money motivation. The main limitation is the narrow scope, emphasizing only users located in Bandung city. This paper may involve more users further to present strong factors about e-money activity. This research presents determinant factors about less active in using e-money among users that may help Telecommunication Company by recovering these elements. This paper gives valuable references to e-money providers to consider factors founded in offering better service for users and improve the amount of super active Ling Aja users in daily transactions. This study provides the determination of dominant factors that cased the less active activity and transaction among users of Link Aja and contributes to a better understanding of how to provide better service of e-money based on these factors for improvement further.

(C) 2019 The authors, under a Creative Commons AttributionNonCommercial 4.0

Corresponding author's email address: irnacut@ telkomuniversity.ac.id

Recommended citation: Setiawati, C. I. \& Falah, N., (2019). E-Money Challenge in Disruption Era: Uncovering the Dilemma Issues from Consumers' Perspective. Sustainable Business and Society in Emerging Economies, 1(2), 109-122

DOI: $10.26710 /$ sbsee.v1i2.1015 


\section{Introduction}

People's economic habits from time to time have changed with the development of technology that ultimately requires all activities to be faster and effective including in the payment system used for trading and financial services (Tonglet, Johnstone, Tonglet, \& Johnstone, 2002). To meet these demands, in Indonesia, innovation in payment technology was established under the supervision of Bank of Indonesia in order to produce a secure technology-based payment system. Looking at these conditions, it is known that the development of the payment system cannot be separated with technological developments, so the evolution of payments in Indonesia today also leads to a payment system based on technological developments, and also transformed from paper money to become electronic money (Dehghan, 2014). The payment technology providers, whether involving banks or non-bank institutions, are equally engaged in the development of the payment system (Dehghan, 2014). There are several forms of technology-based payment offerings and using currency which are considered too risky from customers' perspectives in their day-to-day transactions as well as benefits received such inexpensive, accessible, convenient and lower costs (Coats, 1997)

The latest developments of technology-based payment systems according to Bank of Indonesia are, for example, Bank Indonesia provides Real Time Gross Settlement System (BI-RTGS), which is used preferred for large important value transactions such as monetary management transactions, Government transactions, and interbank money market transactions. There is also a payment system provided named Central Depository and Book Entry Settlement System (C-Best) which is the settlement of funds from securities transactions traded in the capital market. With various types of technology-based payment, Bank of Indonesia began to make it easier for consumers to conduct transactions with Automated Teller Machine (ATM) Networks, Transfer electronic funds using Automated Teller Machine (ATM) card so that consumers no longer need to queue at the bank. Then there is also Money Transfer Operator, providing system or network in the activity of fund transfers either outside Indonesia territory, into Indonesia territory, or in Indonesia territory. In 2009 Bank of Indonesia issued an official regulation concerning electronic money. Because it is perceived that the regulation has not been perfect, Bank of Indonesia made the regulation changes in 2014 and the latest revision in 2016. With the rapid development of technology, not a few companies that make electronic money as one of the innovations in the payment system. Electronic money is electronic payment where the money is stored in the instrument or device used. Electronic money also defines as stored value retail payment instruments which are to be used in place of cash for small value, average, point of sales payment in daily trading (Coats, 1997) In Indonesia, there are 6 banks and 4 telecommunication companies which provide the electronic money innovation for transactions. 6 banks consist of (1) Bank of Central Asia (BCA), (2) Bank Negara Indonesia (BNI), (3) Bank Mandiri, (4) Bank Rakyat Indonesia (BRI), (5) Bank Mega, (6) Bank DKI of Jakarta), and can be used for transportation, retail stores, food \& beverages stores, parking tickets, highways, and others economic activities (Miliani, Purwanegara, Tantri, \& Indriani, 2013)

Electronic money is money used on online and offline transaction that has a unique characteristic of technology in payment methods execution (Miliani et al., 2013). Electronic money as the medium of switchover, has nominal amount of money for transaction in trading, security and portable. Typically, these transactions involve the use of computer networks. Electronic money has a stored-value or prepaid value in which a certain amount of money is stored in an electronic media owned by a person. The value of money in electronic money will decrease as consumers use for payment (Singh, n.d.) Currently, Indonesia is still lagging behind compared to ASEAN countries in terms of payment with electronic money. In Indonesia, based on Bank of Indonesia retail transaction through cash payment is $99.4 \%$ and non-cash payment is $0.6 \%$. Although almost six years of implementation in Indonesia, the number of emoney instruments usage in 2012, was only 21,869,946, about $9 \%$ of Indonesia population (Miliani et al., 2013). To increase the number of non-cash users Bank of Indonesia established a strategy by establishing a Non-Cash National Movement on 14 August 2014. This movement is aimed at increasing public awareness of the use of non-cash transaction systems, thereby gradually establishing community that uses 
the Non Cash transaction system particularly in conducting transactions on its economic activities (Wulandari et al., 2018)

Before discussing more about electronic money and the data that has been found, it is worth reviewing the brief history of electronic money in Indonesia and its current condition. In accordance with the official data and written information we obtained from IndoTelko Forum, electronic money transactions in Indonesia was recorded to reach 1.4 billion per day with the number of transactions only to reach 48 thousand times a year (Overview, 2018). In the following year, the number of electronic money transactions continued to rise sharply to reach 73 thousand times a year with printing transaction value of 1.9 billion per day. The growth trend continues to be followed in the following years, as in 2011 when electronic money transactions jumped to reach 112 thousand times a year with a turnover of 2.7 billion dollars per day. This trend continues to surge when in 2012, electronic money transactions doubled to 219 thousand transactions in a year with business value touching 3.2 billion per day (Miliani et al., 2013). From the growth data, it can be explained that every year electronic money transactions grew about $120 \%$ from year to year, until finally in 2013 this electronic money transactions have penetrated the figure of 6.7 billion per day. It was a very rapid increase. From this growth trend, the most enthusiastic users in using electronic money services come from the mobile community of users who are far more potential. Unfortunately, the survey conducted by IndoTelko Forum to about 2,000 respondents found that there are still some obstacles to be fixed before the electronic money service can become a reliable financial transactions tool.

In contrast to other types of transactions, electronic money is one of the payment system that is not only followed by banks but, in Indonesia, including telecommunications companies namely Telkomsel, Indosat, XL and Smartfren. The participation of these providers in providing electronic money cannot be separated from the large potential of electronic money as an efficient of general payment in the future (Jaffar \& Abdullah, n.d.). In tekno.kompas.com (2012) mentioned that these providers have a great opportunity to support e-money because the number of mobile phone users is much greater than the number of Bank account users in Indonesia. Where users of Bank accounts reached 60 million, the number is much smaller than the growth of mobile phone user's as much as 297 million users in the past 18 years.

Currently Indosat XL and Smartfren started launching electronic money products under the name of Dompetku, Tunaiku, and Uangku following Telkomsel as the first telecommunication company to launch electronic money payment system. The product issued by Telkomsel is Link Aja (previous name was Telkomsel Cash, T-Cash). Link Aja is a micro pay tool in Indonesia. In addition to being used as a paying tool, Link Aja is a service that allows customers to make transactions using mobile phones. Transactions that can be used such as purchases of goods through stores, websites, bill payments, remittances such as transfers between users of Link Aja services. The use of Link Aja itself has been going on since November 2007. First published how to use Link Aja is by accessing *808 \#. Link Aja provides various services including promotion and discount for food and beverages products in some merchants, to make token payments, for money transfers, for credit content, for movie and tickets purchases, payment any bills such electricity, TV cable and phone bill, and also to pay insurance and donation, and for financial services among banks. With the rapid development of technology, Telkomsel innovate and release Link Aja by creating an application and barcode-based that has been connected with the user's mobile phone, so the transaction process becomes easier and faster. This is one of the strategies undertaken by Tekomsel to develop its products.

Telkomsel is an integrator and service provider supported by Bank of Indonesia as a main regulator. Telkomsel cooperates with several banks as depositors such as BNI, Mandiri and BCA. Currently there are merchant-sellers of goods and services, College of academic content providers, and others who work with Link Aja. According to inet.detik.com (2016) McDonald's and Cinema XXI became merchants with the fastest growing transactions. In addition to the two merchants are Bakmi GM, 7-Eleven, Wendy's and 
Coffee Bean (restaurants). Increased transactions occurred with the promo made by Link Aja and merchants such as discounts, cash back and other promotion offerings. Electronic money system owned by Telkomsel has been going on for almost four years, which transformed from T-Cash. In April 2011, data of 4.5 million subscribers of 96 million Telkomsel subscribers were registered as users. While active transfers only $10 \%$ of registered customers.

Based on data from www.publication.gunadarma.ac.id (2016) it is known that about 4.5 million registered as users of Link Aja. In 2011 with a liveliness of 10\%. While in 2016 according to inet.detik.com (2016) the number of registered users was 20 million. But the overall active user is only 6 million which means the activeness rate is only 30\%. Link Aja CEO said that the target is to boost the number of users to about 80 million or 100 million. Based on the interview of the researcher to the Link Aja user about the respondent's opinion on the product, there were some problems such as lack of information regarding the refill of balance, supported by Bank of Indonesia statement (www.bi.go.id), non-cash payment systems in Indonesia continue to increase, but the increase has not significantly reduced the dominance of payments in cash. This condition is due to the relatively low understanding of non-cash instruments and the limited availability of non-cash transactions support equipment. In addition, some of the respondents said the use of Link Aja is limited to the trend of having e-money without any desire to use it actively. The promotions offered by Link Aja are also the reason people have the account, but with promo futures and reduced amounts of discounts also make registered users less likely to use. Finally, systems that are still frequent errors are also the reason for the reduced interest in the effectiveness of registered users in using Link Aja. From the data that has been described, it is known that the number of active users of Link Aja is still minimal caused by several factors that reduce user interest, the authors are interested to conduct research with the aim to determine what factors reduce the activity of Link Aja users in Bandung.

\section{Literature Review}

Money is a big innovation in the world economic civilization (Tonglet et al., 2002). The position of money is very strategic in one economic system and is difficult to replace with other variables (Vlasov, 2017). Money is an integrated part in one economic system (Andrieu, 2001). Throughout the history of its existence, money has played an important role in the course of modern life. Money managed to facilitate and shorten the time of exchange of goods and services (Chiu \& Wong, 2015). Money in the economic system allows trade to run efficiently (Lefebvre, 1999). The stages in the evolution of the payment system began with the barter system. This system is the simplest and most primitive system. Transactions involve direct physical exchange of goods, but this system has the disadvantage that this transaction occurs because of a desire at a certain time. The barter system requires the seller to accept whatever is submitted by the buyer (Coats, 1997). The development of the barter system is becoming more and more difficult this has led to an exchange tool that can be generally accepted as a means of payment in transactions (König, 2001). Money in traditional economics is defined as any medium of exchange that is generally acceptable. The medium of exchange is any object that can be accepted by everyone in the community in the process of exchanging goods and services. Money is something which is widely accepted in payments for goods. Money are those things that are widely used as a media for exchange (Levintal \& Zeira, 2009). Money is something that is widely accepted for the settlements of debts. Money is something that is good, services, and other valuables assets, and for the payment of debts. Money is anything that is commonly accepted as a means of exchange and as a measure of value, which at the same time acts as a means of hoarding wealth (König, 2001). From this definition that everything that had fulfilled this definition was considered money, whether it was made of metal, paper or other objects that had been accepted by the community as a means of exchange, a measure of value and as a means of hoarding wealth. From year to year there is a payment system that makes it easier for humans to conduct transactions such as fiat money, checks, credit or debit cards, and what is being developed in Indonesia is electronic money (Wabutwa, Iegi, \& Ittencourt, 2016). 


\subsection{Electronic Payment System}

Electronic Payment System can be defined as a modern banking service by utilizing technology that can improve performance and enable various activities to be carried out quickly, precisely, and accurately so that it will ultimately increase productivity (Bezhovski, 2016). According to the Federal Financial Institutions Examination Council (2010), electronic payments are a new payment practice for retail where a trader takes payment information for goods and services and places this information in an electronic template that creates electronic files for processing through clearing networks. From the above meanings, it can be concluded that Electronic Payment (E-Payment) is a payment system that can be carried out by several parties such as banking, business (vendors or consumers) and social actors carried out electronically through a technology and information network sophisticated (Jaffar \& Abdullah, n.d.).

According to Turban and King, the parties involved in E-Payment are: 1) Issuer, the bank or non-bank party serving the E-Payment process that is used in buying and selling online. 2) Customers, parties who make payments from buying and selling transactions online. 3) Merchant, the party who receives payment from buying and selling transactions online. 4) Regulator, the government that makes the rules regarding E-Payment (Chiu \& Wong, 2015).

Based on Bank of Indonesia Regulation No. 16/8 / PBI / 2014 concerning Amendments to Bank of Indonesia Regulation No. 11/12 / PBI / 2009 concerning electronic money, electronic money is defined as a means of payment that meets the following elements (Overview, 2018): (1) issued on the basis of the value of money paid in advance to the issuer, (2) value of money that is stored electronically in a medium such as a server or chip, (3) used as a means of payment to traders who are not the issuers of electronic money, (4) the value of electronic money deposited by holders and managed by the issuer is not a deposit as referred to in the law governing banking. Electronic money (E-Money) is money that is used in internet transactions by electronic means. This transaction involves the use of internet networks such as digital pricing storage systems (Khatimah \& Halim, 2009). Electronic money is money used in internet transactions by electronic supported.

Usually, this transaction involves the use of a computer network. Electronic money has a stored value (stored value) or prepaid (prepaid) where a certain amount of money is stored in an electronic media owned by someone. The value of money in electronic money will decrease when consumers use it for payment. Bank for International Settlement (BIS) 1996 defines Electronic money (E-Money) as a stored value or prepared card product for which the amount of money is on an electronic card or can also be called electronic equipment (Kartika \& Nugroho, 2015). The money can be obtained electronically because the process is through depositing a sum of cash into a bank and then from the bank transferring the money with a system of transferring funds or money electronically to the owner. After that the owner will be able to make buying and selling transactions with the card. Where the balance on the card can be reduced or increased (Dehghan, 2014). It is reduced because the owner purchases the item, then the balance increases if the buyer top up or refill the balance. Some benefits or advantages of using electronic money compared to cash and other non-cash payment instruments, including: first, faster and more convenient than cash, especially for small value transactions, because the customer does not need to provide an exact amount of money for a transaction or must save change. Secondly, the time needed to complete a transaction with electronic money can be done much shorter than transactions with a credit card or debit card, because it does not need to require online authorization, a signature or PIN or password. In addition to offline transactions, communication costs can be reduced. Third, electronic value can be topped up into electronic money cards through various means provided by the issuer (Indonesia, n.d.)

In general, electronic money is divided into two types, namely electronic money in the form of cards where the identity of the holder is registered and registered with the issuer or registered and electronic money in the form of a card without the identity of the holder (Andrieu, 2001). In addition, there are also electronic money that uses cellular phones as a storage medium. The advantages of electronic money are 
practical because users don't need to carry physical money. Another advantage is faster transactions, just stick to the card and do not need to count sheets of bills. The next advantage is that users can track every expenditure making it easier to manage finances. The lack of electronic money is that not all providers of goods and services can accept electronic transactions, especially in rural and traditional markets. This electronic money also has the risk of being lost and damaged, especially if we enter a large amount of money, then once the card is damaged or lost, then all our money is lost (Bank of Indonesia, 2016).

The law of electronic money is basically the same as ordinary money because it has a function as a means of payment for buying and selling goods. Therefore, electronic money must meet the criteria and provisions in accordance with predetermined principles (Wabutwa et al., 2016).

\subsection{Factors Drives Less Active of E-Money Usage}

The authority to regulate and maintain the smoothness of the payment system in Indonesia is exercised by Bank Indonesia as outlined in the Bank Indonesia Act. In carrying out this mandate, BI refers to four principles of payment system policies (Indonesia, n.d.), namely:

- Security, means that all risks in the payment system such as liquidity risk, credit risk, fraud risk must be managed and mitigated properly by each payment system operation.

- The principle of efficiency emphasizes that the payment system violations must be widely used so that the costs borne by the public will be cheaper because of the increased economies of scale.

- The principle of equality of access which means that BI does not want monopolistic practices in the operation of a system that can prevent other players from entering.

- Consumer protection, is the obligation of all payment system operators to pay attention to aspects of consumer protection.

Meanwhile, in relation to institutions that circulate money, the clear operation of the payment system is supported by the preservation of the amount of cash in circulation in the community and in conditions that are worthy of circulation or commonly referred to as clean money policy (Khatimah \& Halim, 2009).

Based on the facts obtained from the field through interviews, it is known that there are several factors that make the number of user activeness not optimal and after being traced theoretically, these factors are related to those raised by The implementation of E-Money still has obstacles (Fujiki \& Tanaka, 2014)including:

- High effort to achieve discount, the effort needed to maximize electronic money so that consumers are more open and more modern in transactions.

- Time error is the ease, smoothness, practical and efficient provided but in reality there are many consumers who complain after using e-money in some merchants that should be faster and save time that frequent system errors or error machines that make consumers' time wasted.

- Cost of handling various means of payment, given that many benefits can be taken in transactions using cash Gold Finger believes that it will be difficult for E-Money to get rid of cash if it does not have a good system and network. This causes the company to think repeatedly to join in serving consumers in the use of E-Money given the costs that need to be incurred for the E-Money device that the system and network has not been stable.

- Explicit fees are payments in accordance with the nominal billed if using e-money. More accurate payment calculations compared to cash. Payments using e-money are more accurate and more fixed nominal. However, any amount of fixed costs that are billed will certainly lead to small transactions.

- Risk is theft, loss is one of the obstacles that inhibits e-money in the future.

According to (Yilmaz, 2015) the benefits and advantages of electronic money compared to the use of cash payment transactions and other non-cash tools but in reality are inversely proportional, namely as follows: 
- Machine and system errors, this reality is inversely proportional to what is revealed that transactions using electronic money tend to be faster and more convenient because users do not need to carry exact money or take change after buying and selling, but also avoid mistakes in calculating change.

- Term Password or PIN, in reality every time we will transact using e-money users must enter in the form of a PIN or Password as a security system. But in Indonesia, not all e-money is equipped with a PIN or password. Added to the constraints if the engine error occurs which takes a long time.

- Limited facilities for refilling balances, the value of money or the balance can be refilled into the e-money card through the facilities and facilities that have been provided by the issuer (bank). But in reality there are still many merchants who still do not know and do not understand about how and what e-money is so that consumers can only fill balances at the issuer's own place.

In this world nothing is perfect, likewise with information systems. No matter how good a system is developed, it must have obstacles or weaknesses that make it need to be improved continuously. Of the many features offered by various E-Money products that are developing in Indonesia today, there are some weaknesses. Some of these weaknesses include (Xu, Chen, \& Jiang, 2019) :

- Security issues.

- Interoperability Issues,

- Cannot be refilled through the service provider.

- Merchant partners are still limited, this is a problem faced by almost all publishers of e-money products in Indonesia today. These publishers seem to face difficulties in expanding cooperation with merchants in the context of expanding the use of E-Money.

\section{Methodology}

This research is a descriptive and explorative research with quantitative approach. This study was conducted on people in the city of Bandung who have Link Aja account. This study also examines the factors that influence the attitude of the community itself. Type of measurement scale used in this research is Likert scale. The population in this study is users who live in Bandung that have Link Aja but not active in its use. According to Vice President of MFS Operations Telkomsel that is Rudy Hamdani said until now the average user actively make transactions up to three times a month. So the meaning of the population in this study that is not active in its use is that use Link Aja less than 3 times in one month. Due to the limitations and difficulties of researchers in getting data on the number of people in Bandung who have Link Aja and is not known for sure, then to save time, energy and cost then data collection is done by using Bernoulli formula.

The technique used in this research is non probability sampling technique with incidental sampling type. There is no minimum sample size received in the factor analysis. The larger the sample size, factor analysis becomes more accurate. Preferably the sample size should be 100 or more. Factor analysis cannot be done if the sample size is less than 50. From some of the above opinions, it can be concluded that the study sample is part of the population taken part of the population as a source of data that is considered to represent the entire population. The total sample size is rounded to 100 people to anticipate errors, improve accuracy and reduce the likelihood of bias in factor analysis. The following is the framework of this research. 


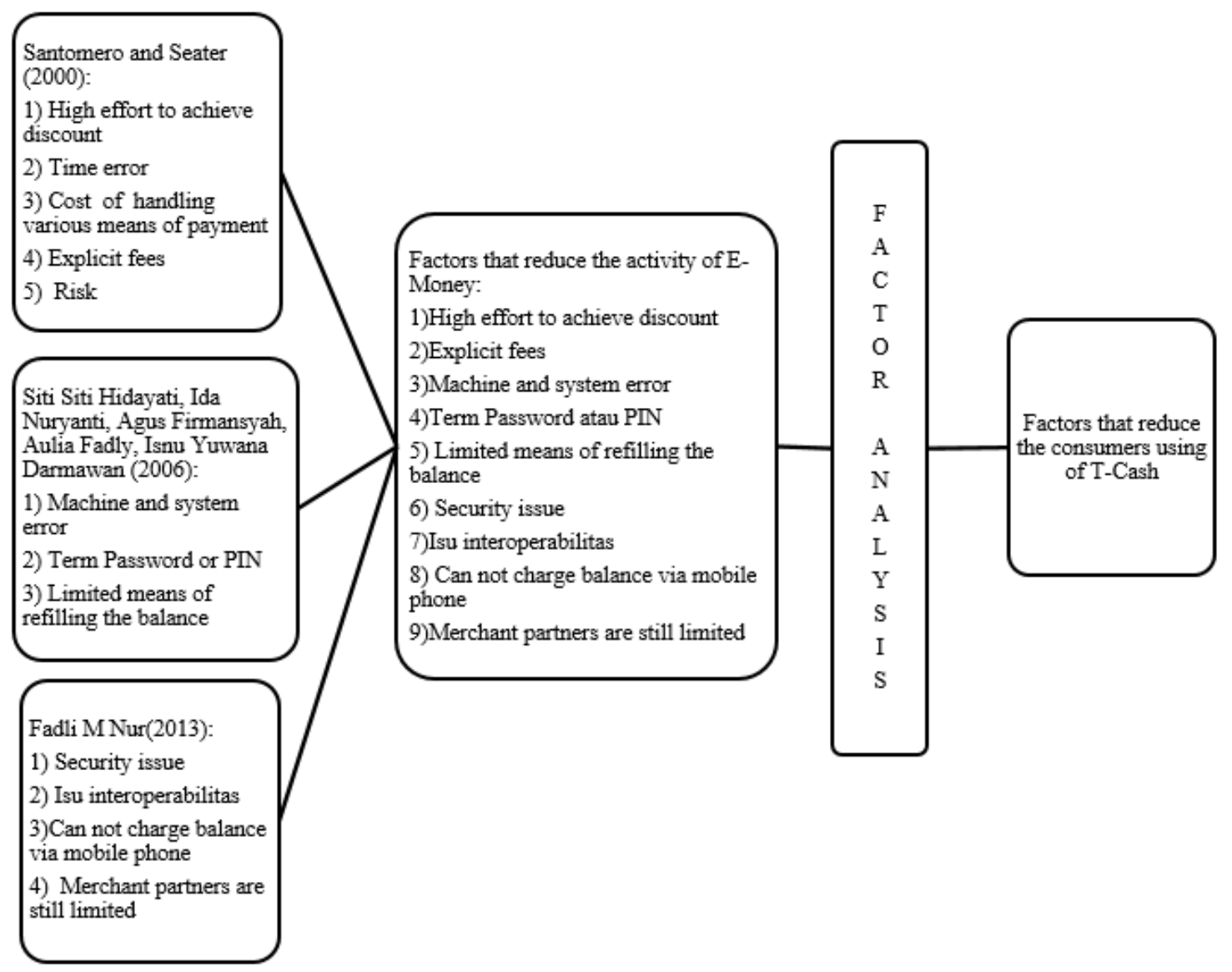

The data collection method in this study is by distributing questionnaires to the people of Bandung who have Link Aja account. Data analysis techniques uses Principal Component Analysis (PCA), which is a factor analysis method that extracts factors using total variance in its analysis. This method produces factors that have the smallest specific variance and error variance. If several factors are produced, the factor that first determines the latent dimensions (hidden dimensions) would become underlies the original variables. After groups are formed, the next step is the process of naming factors or labeling. In factor analysis, judgment is still needed in order to give good results. Thus, the process of naming the factors involved the judgment of the researcher, based on the variables that are components in the groups to make them easier to understand.

\section{Findings/Discussion}

The questionnaires collected from 105 valid respondent's data contained the following results, that as many as $50 \%$ of Link Aja users chose to follow only the current e-money trend motive, and the second points that 33\% as Telkomsel provider users are some owner of Link Aja but not actively use it. However, some others use of Link Aja encourage transaction changes using electronic money but this is still low compared to other $17 \%$ of respondents. So it can be concluded that the use of e-money in particular Link Aja with all the ease and benefits has not attracted the user's desire to be active in its use. Furthermore, to test the accuracy of factor analysis and to know the adequacy of data, the statistical test used is Barlett's Test Sphericity and Kaiser Mayer Olkin (KMO). The calculation result must have a KMO value of 0.5 and if less than that value, then the research may not proceed or factor analysis is not feasible. The total variables used in this study are 9 variables, which are contained in 15 statements and distributed to 105 people in the form of questionnaires. The results of the test variables can be seen in the table below: 
KMO and Bartlett's Test

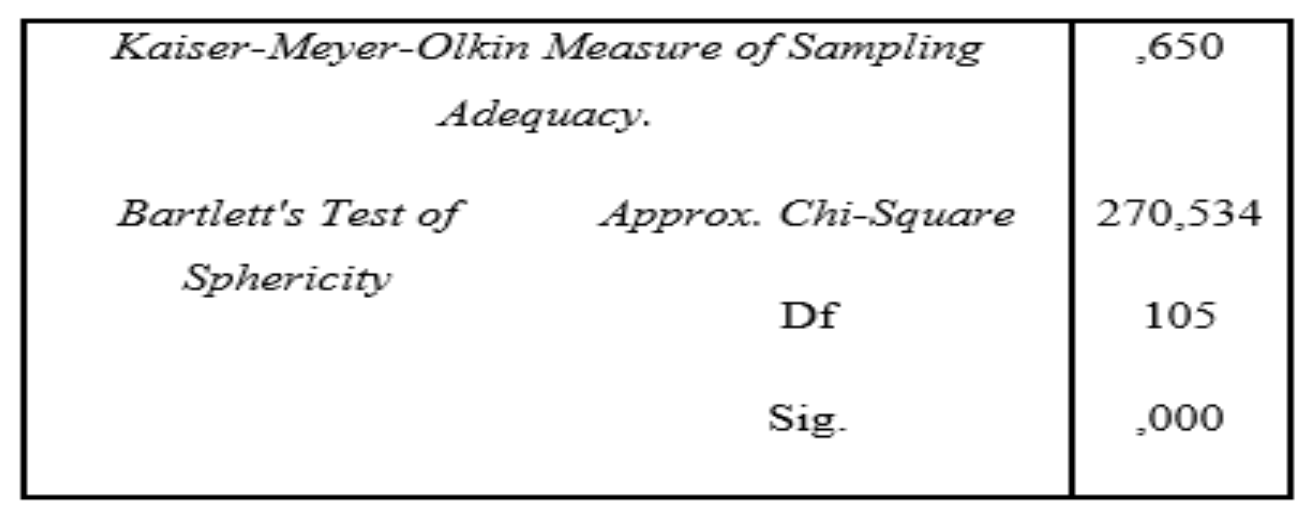

Figure 1. KMO and Bartlett's Test

Based on table above can be seen the value of KMO of 0.650> from 0,500 (minimum value feasibility factor analysis). It can also be seen the Barlett's Test of Sphericity (shown with the Chi Square number) of 270,534 with a significance of 0,000 which means $100 \%$ reliable that inter-variables contain a correlation. With the results of KMO and Barlett's above, it can be concluded that the variables and samples used allow for further analysis. In addition to checking the value of KMO, should also check the value of MSA (Measure of Sampling Adequacy) is to determine whether the variables are partially feasible to be analyzed and not excluded from the test. Furthermore, to see the correlation between independent variables can be considered Anti-Image Matrix. The value of interest is the MSA.

Table 1. Anti-Image Matrix and Communalities

\begin{tabular}{|l|l|l|}
\hline No & Factors & MSA \\
\hline 1 & Must continue to update preconditions and & 0,659 \\
\hline 2 & $\begin{array}{l}\text { Must understand the } \\
\text { conditions }\end{array}$ & 0,6 \\
\hline 3 & Discounts are futures and limited & 0,663 \\
\hline 4 & Additional charge for each balance refill & 0,777 \\
\hline 5 & Use of EDC machine & 0,829 \\
\hline 6 & Network is unstable & 0,5 \\
\hline 7 & Long time to change the new password & 0,534 \\
\hline 8 & Refills on merchants are limited & 0,5 \\
\hline 9 & $\begin{array}{l}\text { Rechargeable ATM are } \\
\text { complicated }\end{array}$ & 0,623 \\
\hline 10 & Writing serial number & 0,639 \\
\hline 11 & Theft or loss & 0,606 \\
\hline 12 & Intervention of other products & 0,734 \\
\hline 13 & No refunding via mobile & 0,718 \\
\hline 14 & The popularity of electronic money is less & 0,556 \\
\hline 15 & Merchant partners are limited & 0,538 \\
\hline
\end{tabular}

Furthermore, the Factoring process is used to determine the new factors that are formed. This study used Principal Component Analysis with total variance, resulting in the smallest specific and error variance. In determining the new factor, it can be done by looking at the eigenvalue. There are 15 factors included in the factor analysis. With each factor having variant $=1$. After the factoring process is carried out, it is 
followed by a grouping of factors. Factor grouping aims to be able to determine each initial variable that is included in the new factor.

The initial variables will enter into the 6 factors that are formed. Grouping of these factors is based on resulting Component Matrix, which shows the distribution of variables that have been extracted into factors and have been formed based on factor loading. Variables are incorporated into the factors that have the greatest loading factor. Factor loading will show the level of closeness of a variable to the factors that are formed. The greater the loading factor, the more obvious variable can be included in one factor. The process of determining the initial variables will enter into the component or factor 1, 2, 3, 4, 5 and 6 is done by performing a large ratio of correlation on each line. The initial variable will enter into the $\mathrm{X}$ factor seen from the largest correlation value. Factor rotation is done to make the large correlation value bigger, and the smaller the correlation value. So the difference in the value of the correlation will be more obvious after the rotation of factors.

Table 2. Component Matrix Rotation

\begin{tabular}{|c|c|c|c|c|c|c|}
\hline \multirow{2}{*}{ Factors } & \multicolumn{6}{|c|}{ Component } \\
\hline & 1 & 2 & 3 & 4 & 5 & 6 \\
\hline Must continue to update &, 309 &,- 059 &, 780 &, 107 &, 238 &,- 089 \\
\hline $\begin{array}{l}\text { Must understand the preconditions } \\
\text { and conditions }\end{array}$ & $\mathrm{s}, 139$ & ,419 &,- 109 &,- 342 &, 506 &, 174 \\
\hline Discounts are futures and limited &, 644 &, 094 &, 172 &,- 249 & ,336 &,- 074 \\
\hline $\begin{array}{l}\text { Additional charge for each balance } \\
\text { refill }\end{array}$ & $\mathrm{e}, 321$ &, 696 &, 027 & 067 &, 035 &,- 088 \\
\hline Use of EDC machine &, 367 & 476 &, 374 &,- 031 & 055 &, 021 \\
\hline Network is unstable &,- 133 & 239 &, 149 & 783 &,- 067 &, 055 \\
\hline $\begin{array}{l}\text { Long time to change the new } \\
\text { password }\end{array}$ & ,073 &, 033 &,- 061 &, 101 &,- 014 &, 832 \\
\hline Refills on merchants are limited &,- 008 & 081 &, 062 & 079 &, 790 &, 013 \\
\hline $\begin{array}{l}\text { Rechargeable ATM facilities are } \\
\text { complicated }\end{array}$ & ,027 &, 201 &, 833 & 063 &,- 087 &, 087 \\
\hline Writing serial number &,- 220 &, 735 &, 199 &, 093 &, 167 &, 004 \\
\hline Theft or loss & 812 &,- 067 &, 132 & 107 &,- 012 &, 009 \\
\hline Intervention of other products & 062 & 350 &, 457 &,- 145 &,- 344 &, 441 \\
\hline No refunding via mobile &, 612 &, 260 &, 042 & 127 &,- 150 &, 202 \\
\hline The popularity of E-Money is less &,- 011 &,- 371 &, 187 & 119 & 272 &, 534 \\
\hline Merchant partners are limited & ,339 &,- 146 &,- 047 &, 713 &, 136 &, 150 \\
\hline
\end{tabular}

Source: Result of statistics conducted by author, 2019

Based on the table above shows that the component matrix after the rotation of factors, can see the factors that are formed and has been spread perfectly into the factors 1,2,3,4,5 and 6. From each component, the numbers are marked yellow is the number that shows the largest component value and is the loading factor of the 15 factors. Based on the above table shows that the component matrix after the rotation of factors, can see the factors that are formed and has been spread perfectly into the factors 1,2,3,4,5 and 6 . From each component, the numbers are marked yellow the number that shows the largest component value and is the loading factor of the 15 factors. Furthermore, component factors 1,2,3,4,5 and 6 will be grouped. Of the 9 initial variables included into the factor analysis, 6 new factors were formed. Then these factors are interpreted according to the variables that have the highest loading value with these factors. In this research the naming factor is based on the highest loading factor on each factor. 6 following factors are formed. 
Table 3. Labelling

\begin{tabular}{|l|l|l|}
\hline Factors & Labelling & Contribution \\
\hline 1 & Security and Limited Discount & $136 \%$ \\
\hline 2 & Explicit fees & $74,52 \%$ \\
\hline 3 & Mechine and Update System & $68,73 \%$ \\
\hline 4 & Network & $53,83 \%$ \\
\hline 5 & Confuse Term and Condition & $50,28 \%$ \\
\hline 6 & $\begin{array}{l}\text { Disadvantage of Time and } \\
\text { Popularity }\end{array}$ & $49,58 \%$ \\
\hline
\end{tabular}

The results showed that there are six factors that are extracted or formed from the process of factor analysis. The six factors are Security and Limited Discount, Explicit fees, Machine and Update System, Network, Confuse Term and Condition, Disadvantage of Time and Popularity. Interpretation of factor names is done by judgment. Because of its subjective nature, the results can be different if the interpretation is done by others. The formed factor can be performed as a new variable replacing the original variables seen from the highest loading factor. Following is the discussion of each factor formed.

\section{Factor 1: Security and Limited Discount}

This factor consists of three items: theft or loss, futures and limited discounts, no refunding via mobile. In the present day it is very often people experience theft or loss, no wonder if the theft or loss is associated with Link Aja. It is clear that one of the functions of Link Aja is to save money, although the nominal amount of money that can be saved is IDR 20.000.000,00 not as much as the amount in ATM. But it is not wrong if we remain alert to theft or loss, because if seen again that the Link Aja itself is small, has the same shape and color so difficult to distinguish between one another, then vulnerable to theft or loss.

Discounted and futures discount factor is one of the factors that encourage the lack of activity in using Link Aja in Bandung city. As already know one of the easiest strategies to attract many consumers to be interested in products by giving discounts as much as possible. The strategy is also used by Link Aja that offer quite a lot of discounts are quite interesting among people such as real example cinema. But the most disappointing is the discount offered only valid one day only on Monday and one Link Aja is only valid for the purchase of one ticket only and very unfortunate the purchase price of cinema tickets using Link Aja currently rises to IDR 25.000,00. This makes the consumers who have been using Link Aja dissatisfied with what has been promised, so one of the factors that reduce the liveliness of using Link Aja one of them is a futures and limited discount. No refunding factor via mobile, is one of the factors that encourage the lack of activity in using Link Aja in Bandung city. Especially in Indonesia charging balances the same way as to buy credit is not yet available.

\section{Factor 2: Explicit Fees}

The contents of the three items of writing serial number, the additional cost of each refill the balance, the use of EDC machine. The factor of writing serial number, is one of the factors that encourage the lack of activity in using Link Aja in Bandung city. This is because the writing of the serial number is small and not obvious. The additional cost factor of each balance refill, is one of the factors that encourage the lack of activeness in using Link Aja in Bandung city. Customers who complain about the additional admin costs when filling the balance of Link Aja in convenient stores, ATM because not a little cost to be incurred that IDR 5000 considering that Link Aja users are among young people so that whatever the cost of admin must be issued will be taken into account. As a real example that has happened to Link Aja users is when he filled the balance and it turns out that the money he had cut by IDR 6,500. For what use emoney if every balance refill alone should incur additional costs, compared to transactions using clearer cash and not burdened with surcharges it is certain that many customers prefer to use cash transactions. 


\section{Factor 3: Machine and Update System}

This factor is called the Machine and Update System factor. Consisting of three items such refill through ATM, should continue to update, other product interventions. Factor refill through ATM complicated, is one of the factors that encourage the lack of liveliness in using Link Aja in the city of Bandung. Recharge at ATMs requires us as users to know the code from Link Aja but the problem is that the code is not listed in the ATM machine, making users confused especially for new users who do not know the code from Link Aja, and cause users to cancel using Link Aja. Factors should continue to update, is one of the factors that encourage the lack of activity in using T-Cash in Bandung city. Because customers are less conscientious in reading the terms of the terms of service, merchant exchanges have a provision limit. So long as customers want an exchange through Link Aja is expected update information via. Another factor of product intervention, is one of the factors that encourage the lack of activity in using Link Aja in Bandung city. Because one EDC machine can only make transactions using certain electronic money. In contrast, Link Aja can only transact on EDC of Link Aja Machine. Indeed, in Indonesia there is no EDC machine available for all electronic money registered with Bank of Indonesia.

\section{Factor 4: Network}

This factor consists of two items: the network is unstable, merchant partner is limited. Network factors are not stable, is one of the factors that encourage the lack of activity in using Link Aja in Bandung city. Due to EDC machines often experience interruption due to fail to cash-in (the contents of the balance), failed to make transactions with information system busy. This means that the network in the EDC machine has not been able to cover in total. The result is that customers are forced to make transactions in retail stores and ATM or other merchants using cash transactions. Unstable network not only in the use of the machine, but there is also an unstable network in the system. On the incident the customer was disappointed. So it creates a sense of dissatisfaction over what is promised by Link Aja that using Link Aja is fast, convenient, and has many benefits.

Limited merchant partner factors, is one of the factors that encourage the lack of activity in using Link Aja in Bandung city. Often found the same merchant but different locations cannot make transactions using Link Aja. In fact, one of the respondents was interviewed and said that when he tried to use Link Aja to fill up the balance in one area, when asked whether in other store can do the Link Aja balance, the cashier replied that there is no machine available for Link Aja but in the brochure which lies next to the checkout written that Link Aja is one of its merchants. So merchants who have joined the branches are not necessarily already joined in serving transactions using Link Aja.

\section{Factor 5: Confuse Term and Condition}

This factor consisting of two items for instance refills on a limited merchant, must understand the prerequisites and conditions. Factor refill on merchants is limited, is one of the factors that encourage the lack of activeness in using Link Aja in Bandung city. Factors must understand the prerequisites and provisions, is one of the factors that encourage the lack of activity in using Link Aja in Bandung city. Many customers use Link Aja without reading the terms of its provisions, as there are some timelines with certain merchants. There are also discounts that have a certain time. So when customers make other transactions on the day, then the discount is different from the specified day. The real example is as follows, there are still many users who have not understood and confused what are the requirements needed to get a discount and how to get discounts offered by Link Aja. Therefore, all users should really know, understand the terms and conditions of any applicable especially for new users so as not to be confused when going to transact using Link Aja.

\section{Factor 6: Disadvantage of Time and Popularity}

Consisting of two items that is a long time for the replacement of new passwords, the popularity of EMoney is less. Long time factor for the replacement of new passwords, is one factor that encourages the lack of activeness in using Link Aja in Bandung city. Change of password if forgot need to GraPari (customer service office) which makes time wasted, rarely call center that help to reset password of Link 
Aja PIN. But it is currently proposed to reset the password manually or via call center. Although there is a manual password reset sometimes customers are constrained to message tokens that do not appear with a description of the busy system. This causes users who want to try using Link Aja inactive in their use. EMoney popularity factor is less, is one of the factors that encourage the lack of activity in using Link Aja in Bandung city. In Indonesia, transactions using e-money is not the main thing, causing the popularity of e-money is less, especially Link Aja can only be used in major cities for sophisticated stores. Although it was trying to enter other areas, but promo offered not all cities can enjoy it so that what is done by Link Aja less than the maximum. This makes the customers have limited space in the use of Link Aja. So for customers who have a hobby of traveling should be patient because Link Aja is not yet available throughout Indonesia.

\section{Conclusion/Implication}

Based on the analysis of this research factor is known to produce several new factors that cause reduced activity in using Link Aja in the city of Bandung. The six factors are Security and Limited Discount, Explicit fees, Machine and Update System, Network, Confuse Term and Condition, Disadvantage of Time and Popularity. By knowing the factors that caused the decreasing of Link Aja electronic user activities in transaction in Bandung, it is expected that to minimize the risk of downsizing the use of Link Aja it is recommended that the company pay attention to every merchant who has joined in transaction processing using Link Aja. Telkomsel as the provider company to pay attention on any discounts given whether it is executed properly according to the rules or not in the merchant concerned. The company is advised to focus more on fixing any minor errors that can reduce the liveliness of using Link Aja first such as unstable, unstable networks in the machine and the system. This study may be a consideration and input ingredient for the company to minimize the risks potentially lead to reduced activity of using Link Aja.

\section{References}

Andrieu, M. (2001). the future of e-money: 03(05).

Bezhovski, Z. (2016). The Future of the Mobile Payment as Electronic Payment System. 8(8), $127-132$.

Chiu, J., \& Wong, T. (2015). On the Essentiality of E - Money.

Coats, W. (1997). Electronic Money: Developments and Issues Electronic Money: Developments and Issues.

Dehghan, F. (2014). E-money regulation for consumer protection. https://doi.org/10.1108/IJLMA-062014-0042

Fujiki, H., \& Tanaka, M. (2014). Currency demand, new technology , and the adoption of electronic money: Micro evidence from Japan. Economics Letters, 125(1), 5-8. https://doi.org/10.1016/j.econlet.2014.07.032

Indonesia, B. (n.d.). Digital Payment Transformation.

Jaffar, S., \& Abdullah, A. (n.d.). Fiat money: from the current Islamic fi nance scholars 'perspective. (1919). https://doi.org/10.1108/H-01-2017-0013

Kartika, V. T., \& Nugroho, A. B. (2015). Analysis On Electronic Money Transactions On Velocity Of Money In Asean-5 Countries. 4(9), 1008-1020.

Khatimah, H., \& Halim, F. (2009). The Intention To Use E-Money Transaction In Indonesia : Conceptual Framework. (2001), 115-124.

König, S. (2001). The Evolution Of Money From Commodity Money to E-Money by. 1-21.

Lefebvre, P. J. (1999). “ Digital money ’' \pm a view from the European Commission. 99(4), 242-256.

Levintal, O., \& Zeira, J. (2009). The Evolution of Paper Money The Evolution of Paper Money.

Miliani, L., Purwanegara, M. S., Tantri, M., \& Indriani, D. (2013). Adoption Behavior of E-Money Usage. 5(7), 369-378.

Overview, A. (2018). PwC Indonesia Legal Alert. (5), 1-4.

Singh, S. (n.d.). Impersonalisation of electronic money: implications for bank marketing. https://doi.org/10.1108/02652320410567926

Tonglet, M., Johnstone, P., Tonglet, M., \& Johnstone, P. (2002). E-Commerce Risks in the 'Open and 
Competitive Market'.

Vlasov, A. V. (2017). The Evolution of E-Money. XX(1), 215-224.

Wabutwa, C. H. N. G. M., Iegi, N. I. V, \& Ittencourt, M. A. B. (2016). Evolution Of Monetary Policy Transmission Mechanism In Malawi : A Tvp-Var Approach. 41(1), 33-55.

Wulandari, D., Malang, U. N., Narmaditya, B. S., Malang, U. N., Parewangi, A. M. A., Indonesia, U., ... Malang, U. N. (2018). Factors Affecting The Adoption Of. 9(7), 1927-1934.

$\mathrm{Xu}, \mathrm{X}$. , Chen, R., \& Jiang, L. (2019). The Influence of Payment Mechanisms on Pricing: When Mental Imagery Stimulates Desire for Money $\Sigma$ Journal of Retailing. https://doi.org/10.1016/j.jretai.2019.08.002

Yilmaz, I. (2015). ScienceDirect Regulating payment services and electronic money: A comparative regulatory approach with a specific focus on Turkish legislation. 1. https://doi.org/10.1016/j.clsr.2015.03.009 